\title{
WOMEN'S ECONOMIC EMPOWERMENT THROUGH HOME BUSINESS FINANCIAL MANAGEMENT IN NORTH KEMBANGAN
}

\author{
Annisa Hakim Z, Nurul Hidayah, Fransisca L. Utami, and Anees Janee Ali \\ Universitas Mercu Buana Jakarta, Indonesia \\ Universiti Sains Malaysia, Malaysia.
}

\begin{abstract}
The growth rate of women entrepreneurs is increasing. This is the most flexible business that can be carried out by women because the main work as a wife and mother can be carried out simultaneously. Women don't need to work outside the home. But the problems that occur there are still women who are not yet entrepreneurs, some are not smoothly running their businesses, so they cannot develop. Therefore, the Community Service Team at Mercu Buana University identified the problems faced by mothers in North Kembangan related to the problems of the business they run. The main problem is the lack of telalten mothers separate business finance with household interests. Thus, the Community Service Team will provide business financial management socialization.
\end{abstract}

Keywords: Women's Economic Empowerment, Home Business Financial Management

\section{INTRODUCTION}

\subsection{Background}

Kembangan District is an area with a high level of population in West Jakarta, especially North Kembangan Village. Data from the Central Statistics Agency (CSA) 2017 shows that the total male population of Kelurahan Kembangan Utara is 30,875 people, while women are 29,752 people. Quantitative potential of female human resources Viewed according to sex, the composition of the productive population turned out to be almost balanced with the population of women and men, namely 71.92 percent compared to 71.97 percent. Although the numbers are almost balanced, the quality of life for women is still lower than that of men. The quantitative potential of this West Jakarta female HR has not yet been balanced with a balanced qualitative potential. In other words, even though there are currently quite a lot of West Jakarta women showing that they are able to compete and at the same time make an equal contribution in various fields of development. Starting from science, technology, politics, economics, social, and even defense and security. But there are still many more Indonesian women who have not been able to show their potential and identity optimally, because they are still constrained by structural, cultural and natural limitations / poverty. This can be seen from the difference in the results of the 2017 national survey that there were still productive ages of women who did not pass elementary school at 13.31 percent.

The low quality of life of women will affect the Indonesian Human Development Index as a whole, especially in strategic fields such as education, health and the economy, which will ultimately have a negative impact on the nation's development process. This shows the condition of the quality of life of Indonesian people is still low and women who have economic potential actually, become a burden of development. Whereas women of prime quality of life can become assets of national development that contribute positively and significantly to the development process that is equitable and equitable.

In the period 2008-2009 Indonesia experienced the impact of the economic crisis that occurred in Europe and the United States so that it also affected the structure of employment. A surge in labor in the informal sector from 2008-2010 showed a percentage that increased from year to year, namely in 2008 amounted to 67.14 percent, increasing in 2009, which was 69.49 percent. This indicates the existence of labor migration from the formal sector to the informal sector in line with the closure and efficiency / rationalization of a number of companies, especially those engaged in the industrial sector and services. The informal sector has an important position as a source of livelihood for most West Jakarta people, especially in North Kembangan Village. Many of Jakarta's residents work in the informal sector, the results of the CSA data show that the business field of North Kebangan residents is in the service sector as many as 3,625 people, the trade sector 6,295, and others as many as 1,661 people, only 1,081 people work in the sector government. Thus the informal sector is much in demand by residents of the North Kembangan village.

The proportion of female workers in the informal sector turns out to cover $70 \%$ of the total female workforce. This indicates that women prefer to enter the informal sector, taking into account the ease, flexibility, 
and flexibility of work in the informal sector which is impossible to obtain when working in the formal sector, such as duties as a wife and mother. However, women who have entrepreneurship have constraints such as aspects of marketing, capital, human resources and technology and the low control of women over production assets.

Even more clear the problems faced by women who have not and have been engaged in entrepreneurship are divided into 4 groups, namely: 1) Women are unable to work because of the burden of poverty, they tend to focus on current needs; 2) women who have not / have not tried, namely women who have problems with attitudes, culture, knowledge and application, have resources but are not motivated, some are motivated but do not have knowledge and skills; 3) women micro entrepreneurs, namely the unavailability of cash to immediately rotate their businesses because household needs are still part of the activity. This group is often the victim of capital service providers with large daily interest; 4) women small and medium entrepreneurs, namely marketing issues, product quality improvement, business management and banking access. Whereas for medium-sized business women usually pay more attention to marketing problems and improve product quality.

The problem experienced by mothers in North Kembangan Village is the problem of the unavailability of cash to immediately run their business because household needs are still part of life activities. This is caused by the absence of good financial management, namely the separation of financial needs of households with business activities. Therefore, the community service team provides socialization and counseling on home business financial management for the women of North Kembangan.

\subsection{Service focus}

The lack of ability of the women of North Kembangan sub-district in managing business finance resulted in the efforts that women had that it was difficult to move forward. This is caused by the absence of separation of money between business and family finance. Thus, it is necessary to provide business financial management socialization, in order to advance the business of women in the North Kembangan village. With the development of women's businesses in the North Kembangan sub-district will increase the economic growth of women in the West Jakarta area, especially North Kembangan.

The socialization of women's business financial management starts from introducing financial problems that often occur to women entrepreneurs and continues by telling them the solution. Thus the women of North Kembangan Village can know the problem in detail and can consult in accordance with the problems faced by the women.

\subsection{Justification and Goals}

The problems of women in starting and running a business are numerous, such as not being able to start a business, having problems with culture, lacking motivation, lack of capital, the inability to manage money, victims of fraud, to problems of supplier and quality of products being marketed. But most of the women in North Kembangan have owned a home-based business, but the problem they face is financial management. Often times the capital doesn't return even runs out. This is due to the absence of financial separation, the inability to manage finances until they are used for daily needs. Thus the socialization of business financial management needs to be carried out in order to be able to contract women's businesses, especially women in North Kembangan.

\subsection{Problem Identification}

From the identification of these problems, several important points were obtained, including:

1. Entrepreneurial women have problems in managing their business finances, so it is necessary to understand the criteria for financial problems of female entrepreneurs, especially the North Kembangan area.

2. North kembangan entrepreneurial mothers need to understand, solutions to problems faced in entrepreneurship.

\subsection{Relevance}

Empowering women in the Indonesian economy is very much needed. This is necessary because it can improve women's social status and help the family's economy. 


\section{Implementation Method}

The methods used in the community service program are tutorials and counseling.

\subsection{Place and time}

The community service program organized by the community service team at Mercu Buana University is carried out in the RPTRA Gajah Tunggal, North Kembangan Village. Participants are women from Kembangan Utara Village, who were chosen by the village government to represent as training participants. Participants are given training and counseling in one day.

\subsection{Activity type}

Community service activities are related to the financial management of women's household businesses as a form of business financial management. This activity takes the form of socialization.

\subsection{Activity Procedure}

Stage 1: Survey the location of activities.

Stage 2: Socialization of financial management of women entrepreneurs

\section{Results and Discussion}

The socialization was carried out at the Gajah Tunggal RPTRA with the community service team first giving a socialization in the form of delivering problems faced by women from starting businesses to developing businesses and their solutions. Furthermore, it provides material on groups of assets, debt, and capital and how to control finances. Thus mothers can manage their business and household finances.

The following are the Achievements of Outcomes of community service activities to be carried out:

Table 1. Achievements Outcomes of community service activities

\begin{tabular}{|l|l|c|}
\hline No & \multicolumn{1}{|c|}{ Outcome Types } & Achievement indicators \\
\hline 1 & Scientific publications in journals / proceedings 1) & \\
\hline 2 & Publication in mass media (print / electronic) 2 & \\
\hline 3 & Increased turnover for partners engaged in the economy 3) & $\sqrt{ }$ \\
\hline 4 & Increasing the quantity and quality of products 3) & \\
\hline 5 & Increased community understanding and skills 3) & \\
\hline 6 & $\begin{array}{l}\text { Improvement of public peace / health (general public partners) } \\
3)\end{array}$ & $\begin{array}{l} \\
\text { Services, models, social engineering, systems, products / } \\
\text { goods 4) }\end{array}$ \\
\hline 8 & $\begin{array}{l}\text { Intellectual property rights (patents, simple patents, } \\
\text { copyrights, trademarks, }\end{array}$ & \\
\hline 9 & Textbook 6) & \\
\hline
\end{tabular}

\subsection{Troubleshooting}

The community service team conducted surveys and interviews with residents related to the smooth running and transfer of business conducted by women in the village of North Kembangan. Furthermore, the community service team made an agreement with residents through the North Kembangan village head. Through the village the invitation was given to the invitation of the residents of the North Kembangan village. The dedication activity is a socialization and counseling on home business financial management for women in the village of North Kembangan which is carried out in the RPTRA Gajah Tunggal, North Kembangan Village. Training and counseling activities for Kembangan village women

1. Implementation begins with the presentation of problems experienced by the group from not starting a business to those who have started a business such as:

a. Women are unable to work because of the burden of poverty, they tend to focus on current needs;

b. Women who have not / have not tried, namely women who have problems with attitudes, culture, knowledge and application, have resources but are not motivated, some are motivated but do not have knowledge and skills;

c. Women micro entrepreneurs, namely the unavailability of cash to immediately rotate their businesses 
because household needs are still part of the activity. This group is often the victim of capital service providers with large daily interest;

d. Women small and medium entrepreneurs, namely marketing issues, product quality improvement, business management and banking access. Whereas for medium-sized women, businesses usually pay more attention to marketing issues and product quality improvement.

It is hoped that the women"”

can analyze the problems they face as to what and how the solutions are.

2. The socialization and information on financial management that has started the business to the women of North Kembanga Village, which consists of

a. Differentiating family finances from business

b. Simple accounting in micro business

\subsection{Results of Activity Implementation}

Through surveys and interviews that have been conducted with village officials and residents in the North Kembangan environment, the Community Service Team subsequently makes invitations to residents who will be distributed by local leaders. Community service activities are in the form of socializing the management of women's business problems to how to manage women's business finance, which is the main obstacle as a smallscale entrepreneur in their neighborhood. The socialization activities of women's business esteem and how to manage women's business finances to residents include the following activities:

1. Implementation begins with the opening of the socialization which was attended by the Community Service Team, the Lurah and his staff and staff. The opening was commenced with a speech from the Lurah, who gave enthusiasm to housewives who participated in the socialization. In addition, the Village Chief also hoped that the women present could apply the knowledge gained in this time's socialization. The Village Head also hopes that Kelurahan Kembangan Utara can develop the Moringa leaf business which is rich in benefits. Thus, the village of North Kembangan could become the main supplier of moringa leaves in Jakarta and could even market as a whole in Indonesia.

2. After the opening of the village leader, a mother who is a kindergarten teacher and has a stall at home participates to give brain exercises to all participants present including the village leader and the Community Service Team. It aims to provide a spirit of joy in participating in the socialization.

3. The next activity, the community service team introduces themselves and explains the purpose of the activity. It is hoped that by introducing the purpose of the activities of the mothers attending the socialization, they will be able to understand what their goals are in joining the socialization.

4. After making an introduction, the Community Service Team starts by introducing the problems that are often experienced by mothers in starting a business up to those who have developed their businesses. This aims to ensure that every woman will start a business until the business runs and develops there are problems to be faced.

5. In the next session, the Community Service Team explained that the most common problem occurred for women entrepreneurs, especially mothers who opened small businesses at home, namely business money mixed with household money. Thus the community service team explains the financial management of the business.

6. The last session, question and answer. For mothers who want to ask about their anxiety in running a business.

7. closing ceremony and taking photos together

\subsection{Discussion}

Socialization of women's economic empowerment: problems facing businesses and business financial management have been carried out in the residents of North Kembangan village. The interest of the residents of the North Kembangan village is very large in participating in the socialization. Mothers pay great attention to the problems of women running businesses. The reason is, the socialization they follow often explains the way or solution.

When the Community Service Team explained that there were four main problems that often became obstacles for women to run a business such as:

1. Women are unable to work because of the burden of poverty, they tend to focus on current needs;

2. Women who have not / have not tried, namely women who have problems with attitudes, culture, knowledge and application, have resources but are not motivated, some are motivated but do not have knowledge and skills;

3. Women micro entrepreneurs, namely the unavailability of cash to immediately rotate their businesses because household needs are still part of the activity. This group is often the victim of capital service 
providers with large daily interest;

4. Women small and medium entrepreneurs, namely marketing issues, product quality improvement, business management and banking access. Whereas for medium-sized women, businesses usually pay more attention to marketing issues and product quality improvement.

The mothers responded, because of these problems they encountered in their lives. In between the explanations there are mothers who talk about their problems, and the most important problem is that their financial management is not so good that often capital is running low because it is often used for household purposes.

Furthermore, the Community Service Team explains how to manage finances in entrepreneurship, dividing finances between household finances and businesses. Thus these problems can be minimized.

In the question and answer session, there were questions that became a general concern for the public, namely the increase in the price of the dollar. They asked whether the cause of the dollar price rose and what they should do. The Community Service Team provides suggestions to participants to start loving Indonesian products. By loving Indonesian products and buying the country's own products the value of prayer will go down by itself, starting with not buying food, clothing, and other foreign products. This is their question because it also impacts the business they live.

\section{Conclusions and Suggestions}

The conclusions that can be drawn from the results of community service by taking the theme of women's economic empowerment are:

1. Participants are not aware that every time they start a business there are obstacles. What type of problem and how to solve the problem.

2. Participants are enthusiastic about the socialization, this can be seen by their busy response when the Community Service Team explains the problems of women's businesses.

3. Participants understand each type of problem for women entrepreneurs and what are the solutions to their problems.

4. Participants understand that they must manage their finances well in order to develop their business to the next stage. Thus household finance and business finance do not mix anymore.

This socialization can be carried out in all parts of Indonesia, because the problem described is a general problem that actually every Indonesian woman faces but many of them do not realize that this is the main problem in running a business. In addition, this socialization also helped the work program of the Ministry of Empowerment of the Indonesian Child Discovery and Protection.

\section{BIBLIOGRAPHY}

BPS.2017.Kesejahteraan Sosial Jakarta dalam Angka 2017, accessed 12 November 2018,https://www.bps.go.id/publication/download.html?nrbvfeve=NWRjMzU5M2I0M2YzZDRhYzFmY jc3MzI0\&xzmn=aHR0cHM6Ly93d3cuYnBzLmdvLmlkL3B1YmxpY2F0aW9uLzIwMTcvMTIvMjgvN WRjMzU5M2I0M2YzZDRhYzFmYjc3MzI0L3N0YXRpc3Rpay1rZXNlamFodGVyYWFuLXJha3lhdC 0yMDE3Lmh0bWw\%3D\&twoadfnoarfeauf=MjAxOC0xMC0yOSAxOTo0Mjo0Nw\%3D\%3D

Economic Gender Mainstreaming Team. 2012. Policies and Strategies for Increasing Women's Economic Productivity. Ministry of Child Empowerment and Protection 